\title{
Educational Tourism as the conceptual age in the University of Surabaya
}

\author{
Veny Megawati \\ University of Surabaya, Surabaya, Indonesia
}

\begin{abstract}
In many major cities in a developed country, a green open space is being promoted as a vacation destination. Besides, the government in the cities in developed countries also provides a museum that is neat and integrated with Simulation Park and playground for children. However, many green open spaces have turned into modern tourism places like shopping malls which may encourage children to be materialistic. To address this issue, parents can actually teach their children any other educational models that are oriented in nature. The nature-oriented models allow childer to create, explore, and stimulate cognitive development, also affective for their motorist skill. The University of Surabaya as one of the best private universities has designed a nature-oriented educational program called "Educational Tourism ".This program was made based on the conceptual age that consists of design, story, symphony, empathy, play, and meaning.
\end{abstract}

Keywords: the conceptual age, educational tourism, University Of Surabaya

\section{INTRODUCTION}

The growth of tourism these days has had a significant enhancement. The trends of the increasing number of needs of traveling by Indonesians can be seen from the rising trends of those travelers in the past decade. Based on the data taken by the Ministry of Tourism, the number of domestic travelers in 2014 had reached 251 million people. It means that the number of people who are "going back and forth" to any tourism destinations had reached the total number of a whole Indonesian citizen.

In many cities in a sophisticated country, the existence of green areas has become one tourist attraction. Besides, the government of those cities also builds museums that are neatly set and integrated with a simulation park where little children can play at. To make it more interesting, these facilities are provided for free.

This particular condition is quite the opposite of those happening in big cities in Indonesia. In other big cities stated above, those green open areas have changed its function and become one modern tourist attraction in the form of malls. As the alternative for mall tourism attraction which tends to encourage materialistic education, parents can actually offer their children any other educational models that are oriented in nature.

On these green open areas, children are not only provided with an entertainment, but also the chance to be creative, to explore, and of course, it can stimulate their cognitive growth and motorist affectivity. The educational activity outside the classroom, which is oriented in nature, have the characteristics of pleasing and can create the spiritual value of the students involved towards the beauty of God's creation through their actions in observing, researching, and independently finding anything that God has created. This kind of method of study will be able to develop and build a fun and challenging learning condition as well as motivate students where they do not only interact with one source of study but also learn from their experiences and interactions towards the surroundings of a certain place that they have visited. More important thing is that they can enjoy their leisure time at a green open area, along with other children who come from a various social background which eventually will train their social ability.

With regards to the matter, the University of Surabaya as one of the best private universities tries to provide a program that is called Educational Tour- 
ism. In more specific matter, this particular unit also meant to make UTC -the representative of the University of Surabaya -an institution which has a strategic role in the history of the conservation of Mount Penanggungan and the development of ecotourism especially in Trawas, and in East Java or Indonesia in general. The existence of this business unit is hoped to be one destination for foreign tourists, considering that the starting point of the concept of educational tourism is started from the concept of from the concept of ecotourism itself (which is focusing on the element of conservation, community, and education) that has now become a global trend of modern society. Through this business unit, the university wants to take part and becomes that particular global trend. With the uniqueness of its product, this business unit is expected to be accepted by various circles of society, and affect not only in the terms of economic profit, but also in the terms of nature sustainability and the welfare of the surrounding community.

\section{THEORY}

Based on Linguists, the term "Pariwisata" (i.e. tourism) comes from the Sanskrit language that consists of two syllables, Pari and Wisatawan. Pari means a whole, all, and full. Wisata means trip. With this, Pariwisata can be described as a full whole trip that is departing from one place, going to and staying in one or several places, and returning to the original place. The term "Pariwisata" is believed to be used for the first time by President Soekarno in a conversation that comes from foreign term tourism. Soekadijo stated that pariwisata is the whole activities in society that is related to tourist. All works including construction of hotels, restoration of cultural heritage, the making of a recreation center, organizing tourism week, the providing transportation and stuff, can be named as a tourism activity as long as throughout the said action more tourists are interested to join one (Soekadijo 1997).

Educational tourism is defined as a program wherein those who joined the activity are going to one particular place, going in a group with the same purpose mainly to gain some experiences in live learning related to the location that they visited (Bodger 1998). The event organizer of such activities can be from educational institutions, such as school or university where the participants coming from or any other institutions such as private educational center or even travel agent. Even though it is called a tourism activity, this particular tour mainly focused on the educational program whose aim is to change one's cognitive and participatory knowledge, skills and participants' behavior (Bhuiyan et al. 2010). Educational tourism can be classified based on the objects or destination places, such as ecotourism, heritage tourism, rural/farm tourism, community tourism and student exchanges between institutions (Smith 2013).

\section{RESEARCH METHODS}

This project This project used the method of action research, where the writer is also acting as the doer in some activities. This study can also be categorized as a single study case, the development of educational tourism located in Trawas, Mojokerto, managed by the University of Surabaya. Data were collected through observation, interviewing the pioneer and implementer of Penanggungan Adventure, and debriefing the surrounding community, and also collecting some documents needed.

The development of educational tourism in this thesis was based on the conservation elements. The activities done throughout the tour will be located in Mount Penanggungan area (especially to those related to historical places as well as its path). The local community is the form of tourism that emphasizes in the rising of surrounding community and provides chances for them to be involved with the process of the development and management, and also gives them chances to get a huge benefit from the said activities.

\section{RESULTS AND DISCUSSIONS}

This study was done to portrait a special program designed by the University of Surabaya by combining the ability of many faculties to design an educational program that is based on nature. This program is called "Educational Tourism". It is designed based on the thoughts of conceptual age that consist of design, story, symphony, empathy, play, and meaning. The first stage of this educational tourism is started from the design stage. The design of this program is based on a back to the nature program, believing that nature is a good teacher. The kind of programs which is offered to participants are: Soft Archaeological Trail, Medium Archaeological Trail, Extreme Archaeological Trail, Amazing Journey, KunangKunang Tour (Sign Thing, Outbond, Fun Games, Bio-Diversity \& Animal Watching, Map \& Compassing, Composing, Happy Farming, Fish Catching, Canyoning, Exploring Durian, Avocado, or Salak, Water Splashing, Rafting, River Tracking, Biking Around The Little Ubud, Forest 4x4 Tour, Exploring Organic Plant and Tasting Organic Food, Bee 
Breeding, Cow and Goat Breeding and any other programs. Children will also be invited to have a direct communication with the surrounding community to teach them how to socialize with others. The existence of the potential of the related community as the tourism partner will make the kind and form of the tourism have more variations. Besides, the close relationship between the University of Surabaya and the surrounding community will make this tourism program last long. In this context, along with the concept of ecotourism, this educational tourism is purposely designed as a tourism program that is also dimensionless towards community development, involving the surrounding community, not only as the object of the tourism but also as the subject of the tourism itself. It means, the surrounding community is not only involved as - for example vendor or supplier the needs in tourism, such as foods or tourism destination (rice fields, farms, etc), but also as a part in managing this tourism program together with the University of Surabaya.

Aside from those explanation mentioned above, this program will also analyze the conservation further through Ubaya Penanggungan Center (UPC) which was built based on the ideas of University of Surabaya as a part of awareness towards cultural and nature preservation in East Java especially in the area around Campus III of University of Surabaya in Trawas that is based on the conservation of nature/cultures. To develop the museums as well as the activities related, the University of Surabaya cooperates with many parties such as East Java Province Government, Mojokerto Regency Government, and many others. The things that are put in these museums are those which are related to artifacts or cites in Mount Penanggungan. UPC is a square place that is divided into 8 parts based on the wind direction of Mount Penanggungan. Artifacts and pictures that were found will then be put in the direction of the wind.

The story that is shown in this program is more into the act of digging historical artifact, and its replica will then be shown, and the placement of those pictures related to the cites, artifacts and various conditions in the past from each zone are available in Mount Penanggungan. Quoted from Wikipedia, Mount Penanggungan is used to be named Mount Pawitra. This name is based on the formation of the mountain that is pointed and on each side is surrounded by smaller mountains, so it looks like a mighty officer. This mountain has the height of $1.653 \mathrm{~m}$ below sea level $(\mathrm{dpl})$. It is one of the conevolcanic mountain or at rest. It is located in Mojokerto Regency (West side) and Pasuruan Regency (East side). Based on the beliefs of Old Java, Mount Penanggungan is one of the parts of
Mahameru Peak that is transferred by the sovereign of nature. Penanggungan is one of the nine sacred mountains in Java. Various ancient temples and hermitage during the Hindus-Buddhist period in East Java are surrounding its hills. Based on the study for two years (2012-2014), there were 116 cites of temples or ancient objects have been found, from the hills until the area near the mountain's peak.

The pictures displayed are the combination of old pictures of Penanggungan sites which were found by researchers from Holland during the period of early 1900 and have been kept in Leiden Museum in the Netherlands. These pictures can be shown up through the cooperation between Ubaya Penanggungan Expedition Team and Leiden Museum. Besides, some artifacts from Majapahit era were also found. Furthermore, this facility will also display the latest pictures of Penanggungan sites as well as its natural surrounding.

Symphony, diversity is beautiful. To support the statement, we also joined in Borobudur Writers \& Cultural Festival (BWCF), an annual festival that is held by Samana Foundation. This festival is a platform for writers and creative workers as well as cultural activists in general wherein they have crossculture discussion and inter-cultural understanding based on the development and broaden one's knowledge over various sources, especially those cultural creators and community who live in the culture itself.

Empathy, in this program, it is expected that the participant's feeling of empathy can grow in the form of awareness towards their surroundings, society and historical artifacts. One of the programs that have been run is, the children are asked to sort out the disposal of organic waste from the non-organic one. They are also invited to socialize with the surrounding community by observing their daily jobs. At first, the children are taught with guidelines of the interview and they must perform it well.

Play, Play, the interests of this activity are proven with the existence of Summer Program in Southeast Asian Art History \& Conservation. This activity is held by the University of Surabaya (Ubaya) together with The Nalanda-Sriwijaya Centre (NSC) at the ISEAS-Yusof Ishak Institute (Singapore), and The School of Oriental and African Studies (SOAS) University of London (England).

Around 40 students and teachers across Asia, Europe, and the USA joined the summer vacation program to some ancient sites of Majapahit Kingdom. Aside from that, they also joined the program to some historical sites in Kediri and Blitar. This Summer Program activity was held for the second time and the theme, for now, is all about the history of old Java artistry. Each participant will be given a 
content which will be followed by some discussions and on field observation.

This activity This activity is very useful for both Indonesian citizen and the future of the site itself. This is because by involving foreign students and teachers, they can exchange their ideas and give each other input. There is one Ph.D. student of Berkeley University in California, USA, Sophia, who stated that this educational tourism is very interesting for her. She admitted that she gained a lot of things throughout the program. Especially the one that is related to those ancient artifacts of the biggest kingdom that once united the whole nation together.

Meaning, with the existence of this educational tourism, it is expected that children will be able to travel in a different way. Unconsciously, those children will eventually gain both education and experiences that are surely unforgettable.

\section{CONCLUSIONS}

The existence of business unit ecotourism or can be called as the educational tourism is expected to enrich the children about the learning process towards one's surrounding, togetherness, national cultures, especially about the history of Majapahit Kingdom. As stated in the background chapter, the concept of this kind of tourism has become the current global trend in the area of tourism. Which is why, it is not impossible that this educational tourism can also become one of a tourist destination, especially foreign tourists. Through this educational tourism, children can have the experience in interacting live with the lives of the local community and the cultures of Indonesia, which will bring them to a whole understanding about society, nature, and Indonesian culture. It will eventually support the growth of economic life of surroundings community of UTC. On top of that, through the synergy with the locals, UBAYA can provide assistance towards society both as a tour guide or managing its natural tourism destination. The existence of tourism destination in the countryside is expected to be able to support the growth of various kinds of businesses.

Through this educational tourism program, it is expected that the children can travel in a different way. Willy-nilly, those children can learn more and gain an unforgettable experiences.

\section{REFERENCES}

Bhuiyana, M.A.H, Rabiul, I., Siwara, R. \& Ismaila, C.S.M. 2010. Educational Tourism and Forest Conservation: Diversification for Child Education. Procedia Social and Behavioral Sciences 7(C).
Bodger, D. 1998. Leisure, learning, and travel. Journal of Physical Education, Recreation \& Dance 69(4).

Smith, A. 2013. The role of educational tourism in raising academic standards. African Journal of Hospitality, Tourism and Leisure 2(3).

Soekadijo. 1997. Anatomi Pariwisata. Jakarta: PT. Gramedia Pusaka Utama 